\title{
HISTORICAL TRENDS OF AIRBORNE TRACE METALS IN DETROIT FROM 1971 TO 1992
}

\author{
NICOLA PIRRONE, GERALD J. KEELER, JEROME O. NRIAGU and \\ PETER O. WARNER * \\ Department of Environmental and Industrial Health, The University of Michigan, Ann Arbor, MI \\ 48109, U.S.A.; * Air Pollution Control Division, Wayne County Department of Public Health, \\ Detroit, MI 48201, U.S.A.
}

(Received 28 April, 1994; accepted 5 March, 1995)

\begin{abstract}
Ambient concentrations of particulate $\mathrm{Fe}, \mathrm{Zn}, \mathrm{Pb}, \mathrm{Ni}, \mathrm{Cr}, \mathrm{Cd}$ and $\mathrm{Hg}$ were measured at nine sites located in the metropolitan area of Detroit from 1971 to 1992. The ambient concentrations of all the trace metals were found to be generally higher at industrial and commercial sites. The concentrations show significant variations between residential and commercial areas and between residential and industrial areas; however, no significant variation was found between the industrial and commercial settings. The spatial variation of trace metal levels within the urban area was influenced by the frequency distribution of the wind direction as well as type and location of emission sources. The ambient concentrations of the trace metals during the decade of 1971-1981 declined by 37$88 \%$. In the 1980 s many of the trace metals reversed this trend with the exception of $\mathrm{Fe}$ and $\mathrm{Pb}$ which continued to decline at annual rates of $2 \%$ and $9.8 \%$, respectively. The sharp decrease in $\mathrm{Pb}$ concentrations during the $1980 \mathrm{~s}$, reflected the significant reduction of $\mathrm{Pb}$ content in gasoline from $0.28 \mathrm{~g} / \mathrm{liter}$ in the 1982 to $0.026 \mathrm{~g} / \mathrm{liter}$ in the 1989 . The ambient concentrations of $\mathrm{Zn}, \mathrm{Ni}, \mathrm{Cr}, \mathrm{Cd}$ and $\mathrm{Hg}$ showed an upward trend during the $1980 \mathrm{~s}$ with an annual rate in the range of $0.6 \%$ to $10.6 \%$. The long-term trends of selected U.S. market parameters, analyzed as potential long-term indicators of emission sources activityies, were consistent with the changes of ambient concentrations, the correlation coefficient being in the range of 0.58 to 0.84 for most of the trace metals.
\end{abstract}

Key words: urban pollution, trace metal, long-term trend, emission source, Detroit, market parameter, land use

\section{Introduction}

The health impact of toxic substances emitted into the atmosphere of the industrialized countries has gained a greater attention from governments and scientific community in the last two decades (Salmon et al., 1978; UN, 19898; WHO, 1992). Changes in fuel composition and consumption (Saltzman et al., 1985), in primary and secondary metallurgical processes, and in waste disposal and land fill operations (Pacyna et al., 1984; Pacyna, 1987; Wilber et al., 1992; EPA, 1993a,b) have altered the levels and types of air pollution in urban areas (EPA, 1992; Keeler et al., 1994) and even in pristine remote areas as well (Schroeder et al., 1987; Nriagu, 1990; Lindqvist et al., 1991; Slemr and Langer, 1992; Swain et al., 1992; Harrison et al., 1993; Keeler et al., 1994). However, few studies have been found in the literature dealing with long-term trends in the ambient air concentrations of trace metals in urban and rural areas (Salmon et al., 1978; Schroeder et al., 1987; Cawse, 1987). 


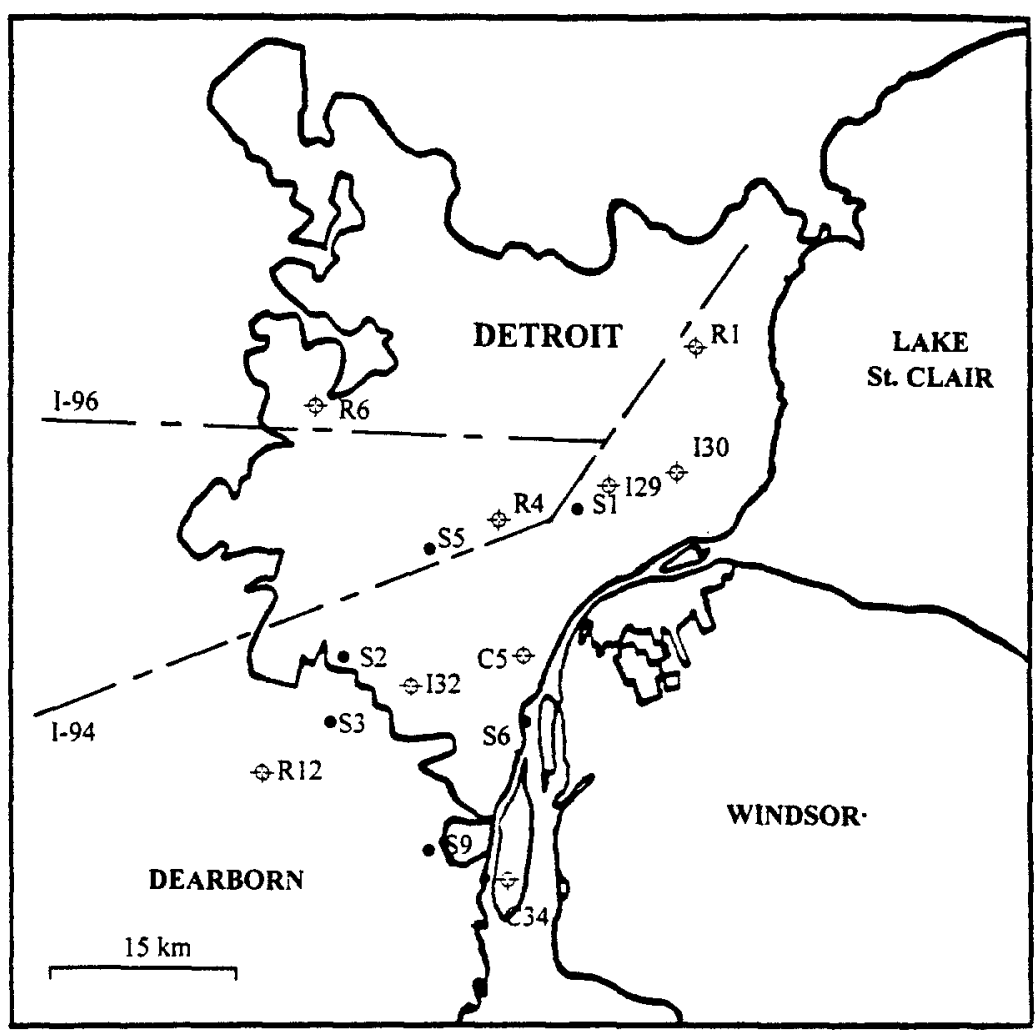

Fig. 1. Sampling sites $(\oplus)$ and major emission sources $(\bullet)$ in the urban area of Detroit, MI. Major emission sources include: S1, GDRRA Incinerator; S2, Central Wayne County Sanitation Authority Incinerator; S3, Automotive assembly plants; S5, Incinerator at Henry's Ford Hospital; S6, Zug Island which include coke ovens, iron-steel plants, and coal power plants; S9, Iron-steel plant; I-94, Highway; and I-96, Highway.

This paper presents two-decade time series and a review of atmospheric trace metal concentrations in the urban area of Detroit, Michigan. Historical patterns effecting the trace metals concentration within the urban area were analyzed including type, size and location of emission sources, land use type, meteorological conditions, and selected market parameters used as long-term indicators of the emission sources activity.

\section{Methods}

\subsection{SAMPLING SITES}

Ambient air concentrations of trace metals associated with particulate matter were measured in Detroit on monthly basis from 1971 to 1992 by the Wayne County 
TABLE I

Coordinates, land use categories and sampling period for each monitoring site in Detroit from 1971 to 1992

\begin{tabular}{lllll}
\hline Site & Latitude & Longitude & Land use category & Sampling period \\
\hline R1 & $42: 25: 51$ & $83: 00: 03$ & Residential & $1971-1992$ \\
R4 & $42: 21: 27$ & $83: 05: 49$ & Residential & $1971-1992$ \\
R6 & $42: 23: 42$ & $83: 14: 06$ & Residential & $1971-1992$ \\
R12 & $42: 18: 76$ & $83: 24: 54$ & Residential & $1971-1986$ \\
C5 & $42: 18: 15$ & $83: 06: 26$ & Commercial & $1971-1992$ \\
C34 & $42: 09: 00$ & $83: 09: 55$ & Commercial & $1971-1989$ \\
I29 & $42: 18: 00$ & $83: 01: 11$ & Industrial & $1987-1991$ \\
I30 & $42: 23: 06$ & $83: 01: 16$ & Industrial & $1987-1991$ \\
I32 & $42: 18: 21$ & $83: 08: 59$ & Industrial & $1971-1989$ \\
\hline
\end{tabular}

Department of Public Health. The sampling was done at nine sites located in residential, commercial and industrial areas. Figure 1 shows the location of sampling sites and major emission sources location in Detroit, and Table I gives the coordinates, land use type and sampling period for each site. Measurements were made in four residential areas: two sites located in north-east (R1) and north-west (R6) Detroit, one site (R4) in central Detroit and one (R12) in Dearborn, a suburban area in the south-west side of Detroit. Two sampling sites were sited in areas of commercial land use: one site (C3 4) was in Grosse Isle $5 \mathrm{~km}$ downwind of a large iron-steel plant (S9), and one (C5) was in the downtown Detroit located 5 $\mathrm{km}$ downwind of Zug Island (S6) which is one of the most industrialized areas of Wayne County. Three sampling sites were sited in industrial areas: two (I29 and I30) were characterized by heavy industries including coke ovens, iron and steel plants, incinerators, power generation facilities and lime and cement operations; a third site (132) was operated in south-east of Dearborn, also a large industrial area characterized mainly by automotive assembly and steel plants.

\subsection{Data ANALYSis}

The main objectives of this study are (a) to analyze the spatial variability of the ambient air concentration of trace metals within the Detroit urban area and to show how the sampling sites are effected by the location and type of the emission sources. Long-term trends of the ambient concentration of trace metals are compared among sampling sites as well as among land use categories. The Student's t-test is used to test the null hypothesis that the univariate sample population means are equal. The results are supported by an analysis of the type and location of emission sources with respect to the sampling sites, long-term meteorological conditions in Detroit, and 
size of the emission source (e.g. for primary and secondary metallurgical processes the overall plant capacity is considered); (b) to analyze the temporal variation of ambient concentrations among cold and warm seasons as well as among the decades 1971-1981 and 1982-1992. Long-term trends of the ambient concentration of trace metals for the decades 1971-1981 and 1982-1992, obtained by least square analysis of the sample-data, are discussed; (c) to identify long-term indicators of the emission sources activity directly or indirectly related with the major U.S. market parameters such as production of metals from primary and secondary metallurgical processes, consumption of metal-based products, import, export and industrial demand of metal-based products as well as the price at London metal exchange; and (d) to compare the long-term trend of the ratio between maximum (Cmax) and average (Caverage) ambient air concentration of trace metals with those of U.S. market parameters assumed as indicators of the emission source activity for a given trace metal. The ratio of Cmax/Caverage is used as indicator of risk-related outdoor exposure to atmospheric contaminants.

\subsection{ANALYTICAL METHODS}

A high-volume sampler equipped with a glass fiber filter iwas used to collect total suspended particulate matter (TSP) at a nominal flow rate of $0.075 \mathrm{~m}^{3} / \mathrm{s}$. Glass fiber strips representing $625 \mathrm{~cm}^{2}$ of filter were loaded into Whatman cellulose extraction thimbles $(33 \times 80 \mathrm{~mm}$ ) and placed into the Soxhlet extraction system (Smoley, 1992). A few boiling chips awere added to each receiving flask containing $150 \mathrm{ml}$ of 1:1 nitric acid, and refluxing allowed to continue for eight hours or more. A $99.9 \%$ extraction of the inorganics was typically achieved. After extraction, the system was cooled to room temperature. The glass fiber pulp and the extractant in the receiving flask were filtered through Whatman 42 filter paper. Metals, especially transition metals such as $\mathrm{Cd}, \mathrm{Cr}$ and $\mathrm{Ni}$ in small amounts, may suffer considerable losses without repeated rinsing using triple distilled water. A total rinse volume of 350-400 ml was often appropriate. Hot distilled water was best suited for the rinsing in order to optimize recovery. Filtrates were collected in $1000 \mathrm{ml}$ beakers and allowed to evaporate to incipient dryness. The residue was dissolved in $5 \mathrm{ml}$ concentrated nitric acid or $5 \mathrm{ml}$ concentrated hydrochloric acid as appropriate. Since a considerable amount of some metals may be lost by volatilization during dissolution of residues in hydrochloric acid, it was important to avoid prolonged exposure or excessive heat in achieving dissolution. The dissolved residues were transferred into $100 \mathrm{ml}$ volumetric flasks and were diluted to volume. Concurrently with the extraction of samples, $625 \mathrm{~cm}^{2}$ of clean glass fiber filter was extracted, filtered and evaporated as above. The residue were dissolved with $5 \mathrm{ml}$ hydrochloric acid and diluted to $100 \mathrm{ml}$ volume served as a reagent and filter blank which was used to correct all quantitative sample data. Composite batch filter blanks were prepared using $30 \mathrm{~cm}$ width cut strips of glass fiber filters from a given batch. A Perkin-Elmer Atomic Absorption Spectrophotometer P-E 3030 was used to 
determine the $\mathrm{Fe}, \mathrm{Zn}, \mathrm{Pb}, \mathrm{Ni}, \mathrm{Cr}$ and $\mathrm{Cd}$ concentrations in the filtrates (Smoley, 1992).

Flameless cold vapor atomic absorption technique was used to determine the mercury (Kermoshchuk and Warner, 1981). In the case of particulate $\mathrm{Hg}$, about 94 $\mathrm{cm}^{2}$ of exposed glass fiber filter was decomposed in $5 \mathrm{ml}$ concentrated hydrofluoric acid in the presence of 10-15 drops of 5\% potassium permanganate. The decomposed sample was subjected to nitric and sulfuric acid oxidation followed by hydroxylamine hydrochloride and stannous chloride reduction of mercury I and II to metallic form (Kermoshchuk and Warner, 1981). An atomic absorption standard addition technique was used to generate a standard curve over the range used to measure metallic mercury.

\section{Results and Discussion}

\subsection{AMBIENT CONCENTRATIONS}

Long-term descriptive statistics are shown in Tables II and III for the decades 19711981 and 1982-1992, respectively. Ambient concentrations of $\mathrm{Fe}$ and $\mathrm{Hg}$ during the 1970s were found to be highest most of the time at industrial site 132. Ambient concentrations of $\mathrm{Cr}$ were found to be highest at $\mathrm{I} 32$ and $\mathrm{C} 5$. $\mathrm{Pb}$ concentrations were found frequently higher at $\mathrm{C} 5$, and $\mathrm{Zn}, \mathrm{Ni}$ and $\mathrm{Cd}$ were found to be more abundant at $\mathrm{C} 5$ and $\mathrm{C} 34$. The ambient concentration of trace metals measured in Detroit from 1971 to 1992 were generally consistent with those observed in other conurbations in North America and Europe during the 1970s and 1980s (Table IV) with the exception of $\mathrm{Pb}$ and $\mathrm{Cd}$ concentrations that were lower than those summarized in Table IV during the 1970s. The $\mathrm{Zn}$ concentrations in the 1980s and Ni concentrations in the 1970s tend to be higher than those found in other urban areas.

\subsection{NORMALIZED MAXIMUM CONCENTRATIONS Vs. EMISSION SOURCE INDICATORS}

Long-term trends of the Cmax/Caverage ratio of trace metals in Detroit during the decades 1971-1981 and 1982-1992 are compared with those of U.S. market parameters which are related to a wide range of metal-based products. The latter have been used as trend indicators for urban areas with a large industrial activity as Detroit. Figure 2 provides, for each trace metal, a comparison between the longterm trends of the Cmax/Caverage ratio and those of U.S. market parameters such as production and consumption, import and price at London metal exchange of metal-based products.

As shown in Figure 2a, the Cmax/Caverage ratio and the U.S. production of Fe-based products including pig iron, steel and iron ore have similar trends with maximum values occurring in the 1973, 1976 and 1981 during the first decade 
TABLE II

Long-term descriptive statistics of the ambient air concentration $\left(\mathrm{ng} / \mathrm{m}^{3}\right)$ of trace metals measured in Detroit from 1971 to 1981

\begin{tabular}{|c|c|c|c|c|c|c|c|}
\hline & $\mathrm{R} 1$ & $\mathrm{R} 4$ & R6 & R12 & $\mathrm{C} 5$ & C34 & I32 \\
\hline \multicolumn{8}{|l|}{$\mathrm{Fe}$} \\
\hline mean & 1406 & 1942 & 1182 & 1802 & 3431 & 2944 & 5250 \\
\hline median & 1098 & 1985 & 1120 & 1616 & 3123 & 3197 & 4898 \\
\hline s.d. & 990 & 763 & 716 & 1001 & 1281 & 1058 & 2614 \\
\hline $\min$ & 402 & 995 & 222 & 923 & 630 & 1085 & 819 \\
\hline $\max$ & 3054 & 3054 & 3054 & 3054 & 5255 & 4615 & 9778 \\
\hline \multicolumn{8}{|l|}{$\mathrm{Zn}$} \\
\hline mean & 244 & 345 & 748 & 263 & 1135 & 930 & 1189 \\
\hline median & 228 & 308 & 308 & 318 & 675 & 529 & 620 \\
\hline s.d. & 88 & 115 & 1001 & 100 & 1335 & 1221 & 1173 \\
\hline $\min$ & 160 & 253 & 130 & 148 & 233 & 205 & 355 \\
\hline $\max$ & 360 & 513 & 3383 & 323 & 4903 & 4275 & 4070 \\
\hline \multicolumn{8}{|l|}{$\mathrm{Pb}$} \\
\hline mean & 621 & 745 & 1853 & 457 & 758 & 311 & 552 \\
\hline median & 625 & 795 & 648 & 466 & 743 & 255 & 505 \\
\hline s.d. & 192 & 235 & 4223 & 165 & 295 & 137 & 299 \\
\hline $\min$ & 233 & 290 & 183 & 238 & 245 & 168 & 125 \\
\hline $\max$ & 978 & 1115 & 14563 & 828 & 1420 & 563 & 1280 \\
\hline \multicolumn{8}{|l|}{$\mathrm{Ni}$} \\
\hline mean & 26.0 & 46.0 & 21.5 & 26.1 & 51.5 & 30.7 & 44.5 \\
\hline median & 16.5 & 37.5 & 17.7 & 17.8 & 34.0 & 32.1 & 42.3 \\
\hline s.d. & 20.2 & 39.6 & 14.4 & 21.3 & 39.8 & 15.4 & 34.1 \\
\hline $\min$ & 8.3 & 10.8 & 5.5 & 6.0 & 8.8 & 8.0 & 12.0 \\
\hline $\max$ & 75.5 & 148.5 & 51.8 & 69.3 & 116.0 & 54.5 & 130.3 \\
\hline \multicolumn{8}{|l|}{$\mathrm{Cr}$} \\
\hline mean & 8.3 & 9.5 & 5.4 & n.a. & 10.6 & n.a. & 10.8 \\
\hline median & 8.3 & 9.5 & 5.4 & n.a. & 10.6 & n.a. & 10.8 \\
\hline s.d. & 2.4 & 1.4 & 2.3 & n.a. & 5.8 & n.a. & 6.4 \\
\hline $\min$ & 6.7 & 8.5 & 3.8 & n.a. & 6.5 & n.a. & 6.3 \\
\hline $\max$ & 10.0 & 10.5 & 7.0 & n.a. & 14.8 & n.a. & 15.3 \\
\hline \multicolumn{8}{|l|}{$\mathrm{Cd}$} \\
\hline mean & 5.9 & 3.8 & 3.0 & 3.2 & 7.2 & 4.0 & 6.6 \\
\hline median & 3.3 & 4.1 & 2.7 & 3.1 & 6.3 & 3.8 & 5.5 \\
\hline s.d. & 8.3 & 1.1 & 1.4 & 1.6 & 2.7 & 1.4 & 3.6 \\
\hline $\min$ & 1.5 & 2.3 & 1.3 & 1.0 & 3.7 & 2.0 & 2.9 \\
\hline $\max$ & 30.6 & 5.3 & 6.3 & 6.8 & 12.0 & 6.9 & 15.2 \\
\hline
\end{tabular}


TABLE II

Continued.

\begin{tabular}{lccccccc}
\hline & R1 & R4 & R6 & R12 & C5 & C34 & I32 \\
\hline Hg & & & & & & & \\
mean & 0.36 & 0.57 & 0.34 & 0.32 & 0.62 & 0.48 & 0.78 \\
median & 0.33 & 0.53 & 0.35 & 0.30 & 0.62 & 0.49 & 0.45 \\
s.d. & 0.21 & 0.28 & 0.11 & 0.10 & 0.29 & 0.18 & 0.70 \\
min & 0.19 & 0.27 & 0.17 & 0.20 & 0.33 & 0.20 & 0.23 \\
$\max$ & 0.90 & 1.08 & 0.57 & 0.47 & 1.13 & 0.73 & 2.38 \\
\hline
\end{tabular}
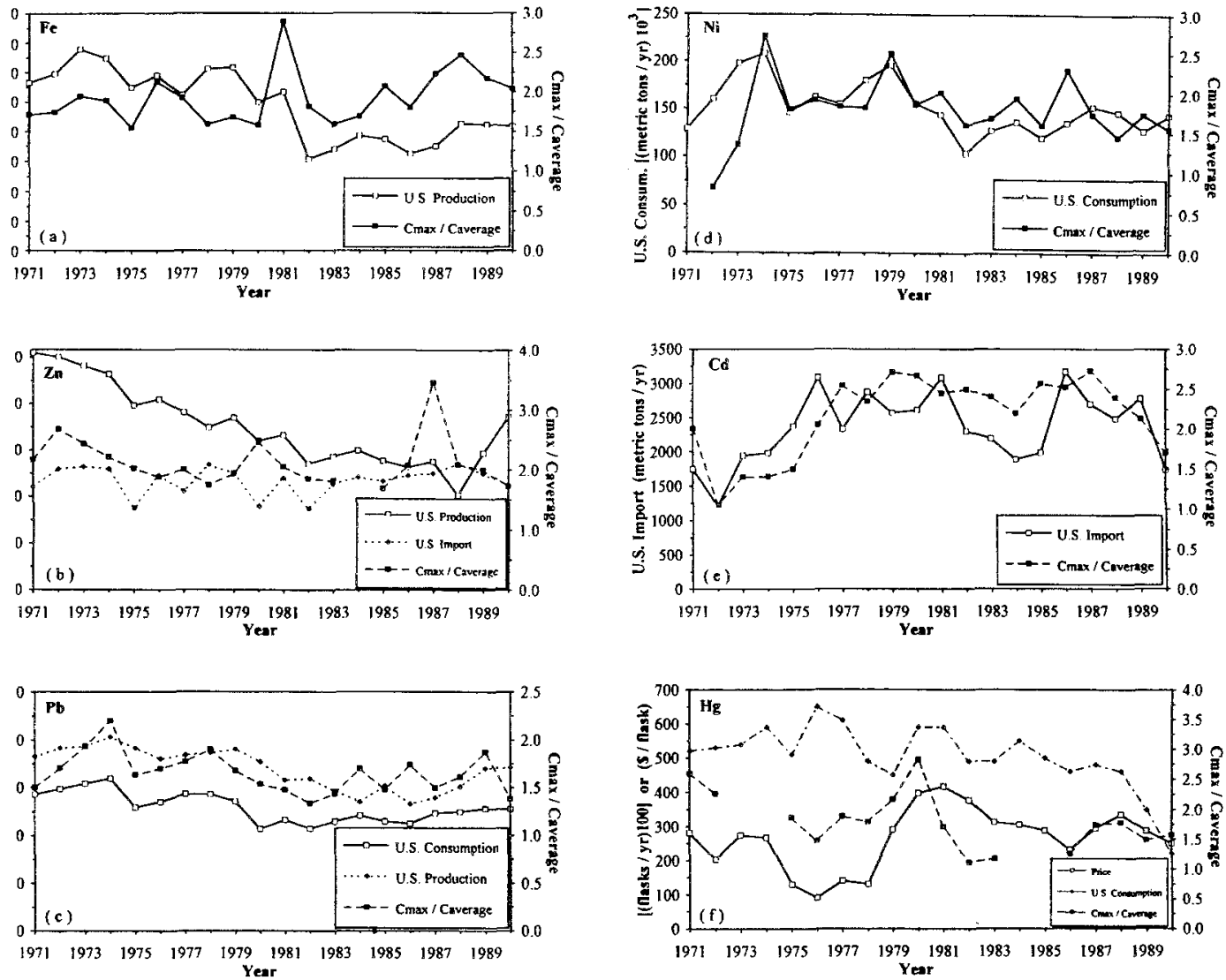

Fig. 2. Comparison between long-term trends of the Cmax/Caverage ratio in Detroit, MI with those of major market parameters observed in the United States from 1971 to 1992. 
TABLE III

Long-term descriptive statistics of the ambient air concentration $\left(\mathrm{ng} / \mathrm{m}^{3}\right)$ of trace metals measured in Detroit from 1982 to 1992

\begin{tabular}{|c|c|c|c|c|c|c|c|}
\hline & R1 & R4 & R6 & $\mathrm{C} 5$ & $\mathrm{I} 29$ & I 30 & 132 \\
\hline \multicolumn{8}{|l|}{$\mathrm{Fe}$} \\
\hline mean & 522 & 717 & 440 & 1423 & 804 & 1538 & 1974 \\
\hline median & 543 & 673 & 435 & 1398 & 558 & 1438 & 1180 \\
\hline s.d. & 99 & 180 & 109 & 404 & 504 & 994 & 1788 \\
\hline $\min$ & 320 & 420 & 243 & 773 & 253 & 213 & 243 \\
\hline $\max$ & 615 & 1013 & 625 & 2090 & 1808 & 3475 & 5645 \\
\hline \multicolumn{8}{|l|}{$\mathrm{Zn}$} \\
\hline mean & 198 & 203 & 127 & 331 & 362 & 302 & 458 \\
\hline median & 129 & 181 & 91 & 269 & 358 & 256 & 517 \\
\hline s.d. & 214 & 83 & 81 & 156 & 283 & 213 & 211 \\
\hline $\min$ & 87 & 123 & 68 & 180 & 55 & 57 & 158 \\
\hline $\max$ & 793 & 425 & 308 & 695 & 885 & 791 & 825 \\
\hline \multicolumn{8}{|l|}{$\mathrm{Pb}$} \\
\hline mean & 99 & 119 & 95 & 156 & 86 & 134 & 86 \\
\hline median & 68 & 77 & 57 & 116 & 69 & 111 & 75 \\
\hline s.d. & 84 & 97 & 86 & 105 & 47 & 102 & 32 \\
\hline $\min$ & 27 & 35 & 20 & 39 & 49 & 36 & 52 \\
\hline $\max$ & 260 & 313 & 265 & 325 & 188 & 360 & 143 \\
\hline \multicolumn{8}{|l|}{$\mathrm{Ni}$} \\
\hline mean & 9.9 & 10.3 & 8.3 & 14.4 & 7.5 & 13.8 & 11.1 \\
\hline median & 8.3 & 9.8 & 6.3 & 12.3 & 5.6 & 11.9 & 12.0 \\
\hline s.d. & 3.7 & 2.9 & 3.7 & 4.0 & 3.6 & 8.9 & 5.3 \\
\hline $\min$ & 5.0 & 6.8 & 4.0 & 9.8 & 4.5 & 6.0 & 4.8 \\
\hline $\max$ & 15.8 & 17.8 & 13.5 & 19.8 & 14.5 & 32.5 & 20.3 \\
\hline \multicolumn{8}{|l|}{$\mathrm{Cr}$} \\
\hline mean & 6.9 & 7.6 & 6.2 & 10.9 & 7.2 & 9.4 & 11.2 \\
\hline median & 6.0 & 6.2 & 4.8 & 9.7 & 5.3 & 7.1 & 11.8 \\
\hline s.d. & 2.8 & 3.1 & 3.9 & 4.3 & 4.0 & 4.8 & 6.5 \\
\hline $\min$ & 3.4 & 4.7 & 1.5 & 6.0 & 4.2 & 5.8 & 2.6 \\
\hline $\max$ & 12.3 & 14.8 & 16.0 & 19.8 & 17.0 & 19.8 & 24.8 \\
\hline \multicolumn{8}{|l|}{$\mathrm{Cd}$} \\
\hline mean & 2.1 & 3.1 & 1.9 & 6.8 & 2.6 & 3.8 & 3.3 \\
\hline median & 2.1 & 2.8 & 1.6 & 6.4 & 2.3 & 4.1 & 3.2 \\
\hline s.d. & 0.6 & 1.8 & 0.6 & 2.3 & 1.4 & 1.4 & 1.5 \\
\hline $\min$ & 1.1 & 1.0 & 1.1 & 4.3 & 0.9 & 1.5 & 1.5 \\
\hline $\max$ & 3.1 & 12.0 & 3.0 & 11.9 & 5.5 & 5.7 & 5.5 \\
\hline
\end{tabular}


TABLE III

Continued.

\begin{tabular}{lrrrrrrr}
\hline & R1 & R4 & R6 & C5 & I29 & I30 & I32 \\
\hline Hg & & & & & & & \\
mean & 0.25 & 0.20 & 0.26 & 0.30 & 0.25 & 0.29 & 0.27 \\
median & 0.20 & 0.22 & 0.21 & 0.27 & 0.19 & 0.23 & 0.30 \\
s.d. & 0.13 & 0.09 & 0.11 & 0.10 & 0.12 & 0.12 & 0.08 \\
min & 0.12 & 0.06 & 0.14 & 0.18 & 0.12 & 0.18 & 0.14 \\
max & 0.55 & 0.38 & 0.48 & 0.53 & 0.48 & 0.55 & 0.35 \\
\hline
\end{tabular}

and in the 1985 and 1988 during the second decade. Between the 1971 and 1981 a similar trend was also followed by the export of the major iron-steel products. This is consistent with the maximum of U.S. consumption and minimum of U.S. import established during the same years for the iron-steel products. During the 1980s the U.S. production and Cmax/Caverage ratio showed notable peaks in 1985 and 1988. These peaks can be related to (a) the U.S. consumption of iron ore that reached a maximum in the 1988 with 84 million metric tons; (b) maximum export of the major Fe-based products; and (c) efficiency trend of the U.S. steel production which was highest in the 1988 with a coefficient of raw steel utilization of $89.2 \%$ (U.S. Bureau of Mines, 1990; Pirrone et al., 1995).

The long-term trends of the Cmax/Caverage ratio and U.S. primary production of the $\mathrm{Zn}$-based products were downward for both the 1970s and 1980s as shown in Figure 2b. The significant increase of the Cmax/Caverage ratio which occurred for $\mathrm{Zn}$ in 1972 and again in 1980 was associated with one of the highest U.S. consumption and lowest price of the $\mathrm{Zn}$-based products observed during the $1970 \mathrm{~s}$. However, the highest Cmax/Caverage ratio which occurred in the 1987 was not associated with a comparable variation in the U.S. production and import of $\mathrm{Zn}$ based products, and may be related to local events. It corresponds with the year when the Double Eagle Steel Co. (S6) located in Detroit began the operation of two new electrolytic galvanizers with a combined capacity of 700 metric tons and equipped with six new ceilcote crossflow scrubbers (Pirrone et al., 1995). It may also be noted that the U.S. consumption of the slab zinc, the zinc content of ores and concentrates, and secondary materials also showed a maximum in the 1987 (Pirrone et al., 1995).

The production and consumption of lead in the U.S. were highest in 1971-1974. During the same period, the Cmax/Caverage ratio reached a value of 2.2 which represented the maximum observed during the 1971-1990 period. A downward trend was observed for both market parameters and the Cmax/Caverage ratio during the 1974-1983 period, however from 1984 to 1990 the trends were upwards for all the parameters considered here (see Figure 2c). 


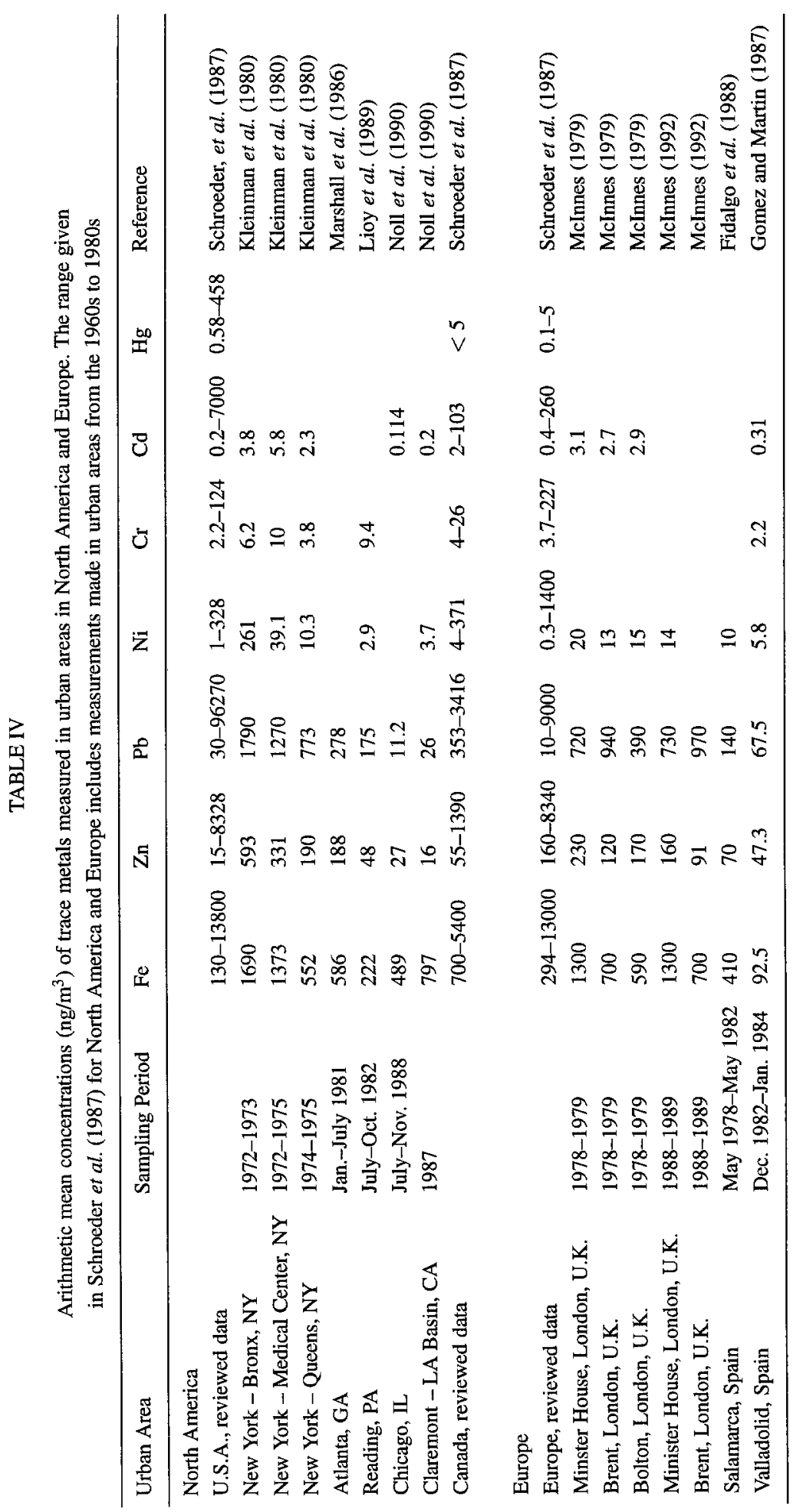


In 1974 both the Cmax/Caverage ratio and U.S. consumption of Ni-based products reached their highest value of the 1971-1990 period (see Figure 2d). In the 1979 there occurred the second highest variation of the Cmax/Caverage ratio, which was associated with the second highest U.S. consumption established during the 1970s. It is interesting that during the same year, the price at London metal exchange ended a long-upward trend which began in 1966; the significance of the similarity in trends is not clear. During the 1980s the largest variation of the Cmax/Caverage ratio was found not to be associated with a comparable variation in any of the parameters discussed here; the parameters usually analyzed as indicators of the emission source activity such as U.S. production, U.S. import and export show one of the lowest values observed during the 1980s.

The long-term average (from 1970 to 1990) of the U.S. consumption pattern for $\mathrm{Cd}$ is as follow: batteries, $40 \%$; coating and plating, $25 \%$; pigments, $13 \%$; plastic and synthetic products, $12 \%$; and alloys and other, $10 \%$ (U.S. Bureau of Mines, 1980,1990 ). Based on this consumption pattern, it is clear that the disposal of Cd-based products such as colored paper, plastic and synthetic products through incineration as well as the weathering of painted-building surfaces and corrosion of plated-metal products may represent an important source $\mathrm{Cd}$ emitted into the urban atmosphere. The U.S. import of Cd-based products seems to be a good long-term indicator of the emission source activity, since it supplies about the $65 \%$ of the total U.S. industrial demand for the element, including waste and scrap as well as cadmium concentrates. From 1976 to 1986 the Cmax/Caverage ratio and the U.S. import of Cd-based products were highest on a long-term average basis (see Figure $2 \mathrm{e})$. During the same period the U.S. consumption of Cd-based products followed a similar trend; however, the higher U.S. industrial demand for $\mathrm{Cd}$ is consistent with the downward trend of the price at London metal exchange.

In the 1970s and 1980s the long-term average of the U.S. consumption of $\mathrm{Hg}$ was 1900 metric tons and 1590 metric tons, respectively. The typical U.S. consumption pattern for $\mathrm{Hg}$ in the last twenty years was approximately as follows: batteries, $50 \%$; paints, $13.6 \%$; chlorine and caustic soda preparation, $12.4 \%$; measuring devices, $6 \%$; wiring devices, $4 \%$; dental equipment, $2 \%$; electrical lighting, $1.7 \%$; and miscellaneous, $10.3 \%$ (U.S. Bureau of Mines, 1980, 1985, 1990). The significant increase of the Cmax/Caverage ratio of $\mathrm{Hg}$ occurring in Detroit in the 1980 corresponded with one of the highest increases in the U.S. industrial demand for the metal and the price at London metal exchange, as showed in Figure $2 \mathrm{f}$.

The slope of long-term trends of the Cmax/Caverage ratio and those obtained for the major U.S. market parameters are given in Table V for the 1970s and 1980s. The trends of U.S. market parameters are consistent with those of the Cmax/Caverage ratio for most of the trace metals (correlation coefficient $r$ in the range of 0.54 to $0.82)$. For $\mathrm{Hg}(\mathrm{r}<0.4)$, however, the U.S. consumption follows a downward trend much slower than that observed in the Cmax/Caverage ratio. The disparity may be due to the effect of three parallel developments: (a) In 1990 the EPA banned the use of $\mathrm{Hg}$ in many industrial processes resulting in a continuous decline in 
NICOLA PIRRONE ET AL.

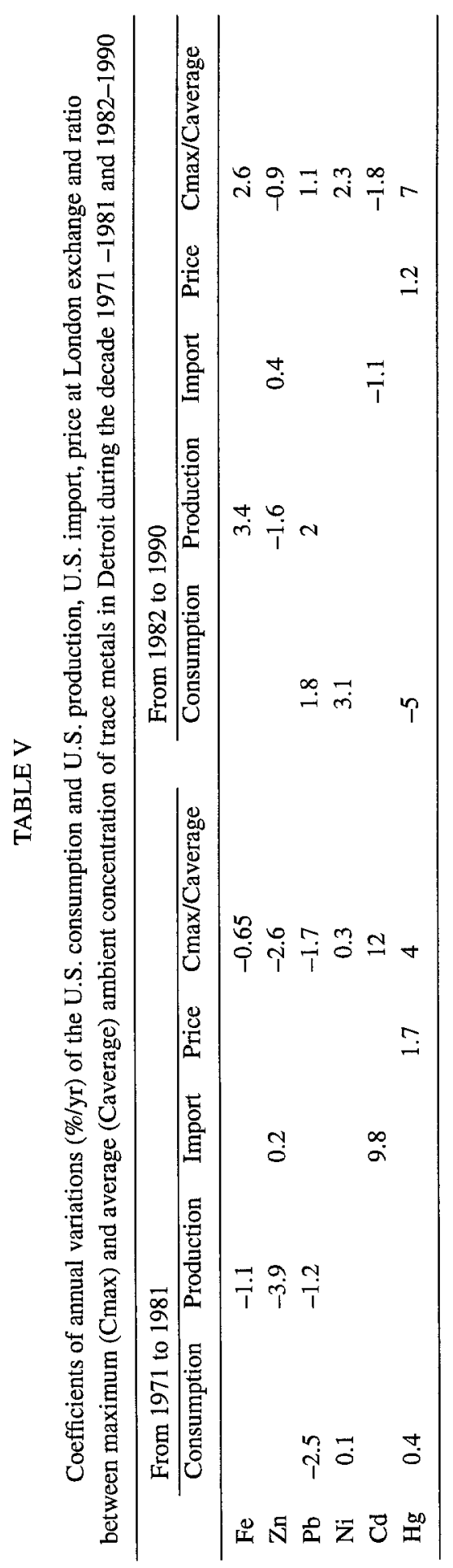


the industrial demand of $\mathrm{Hg}$ after 1988, and producing a decrease in the U.S. consumption of $\mathrm{Hg}$ by $50 \%$ in 1990 compared to 1988; (b) the average life time for most of the $\mathrm{Hg}$-based products is in the range of 8 to 16 years (U.S. Bureau of Mines, 1990), implying that a large fraction of the 1970s products concluded their serviceable lives from middle to later 1980s, and were disposed of by waste incineration processes and landfill operations; and (c) the volatilization of $\mathrm{Hg}$ from large bodies of water and emissions from natural sources (Nriagu, 1989; Lindqvist et al., 1991) represent an important fraction of $\mathrm{Hg}$ lost into the atmosphere which should not be related to any temporal trends in $\mathrm{Hg}$-market parameters observed in the United States during the 1980s.

\subsection{Spatial ANd Temporal VARiability}

Table VI shows the t-test results $(\alpha=0.05)$ between pairs of sites operating in the same land use category and between pairs of land use categories. Significant differences ( $\mathrm{t}>3$ and $\mathrm{P}<0.003$ ) were found between populations of $\mathrm{Fe}, \mathrm{Pb}$, $\mathrm{Ni}$ and $\mathrm{Cr}$ at residential sites and between populations of $\mathrm{Fe}, \mathrm{Zn}, \mathrm{Pb}, \mathrm{Cr}$ and $\mathrm{Cd}$ at commercial sites. At industrial sites all the elements did not show significant differences, with exception of $\mathrm{Fe}$ and $\mathrm{Cd}$ among the sites $\mathrm{I} 29$ and $\mathrm{I} 32$, and $\mathrm{Pb}$ and $\mathrm{Hg}$ among the sites I29 and I30.

The significant differences $(\mathrm{t} \geq 3.5$ and $\mathrm{P}<0.003)$ in population means of $\mathrm{Fe}$ at residential sites suggest the influence of both crustal and anthropogenic sources. Wind-blown soil particles and dust resuspension represent an important source of particulate Fe entering into the urban atmosphere, and this may become even more significant in residential areas where the fraction of exposed soil is larger $(>60 \%$ of the total area). The wind wafting of soil and dust becomes higher during warm seasons compared to the cold seasons (Nicholson, 1988), as shown by the difference in the ratio of the winter and summer ambient air concentrations at residential and commercial sites (Table VII). The higher variance and mean concentrations of Fe and $\mathrm{Zn}$ at $\mathrm{R} 4$ and $\mathrm{C} 5$ suggest the contribution of local sources. The site $\mathrm{C5}$ is in a commercial area with a large number of storing sites for galvanized pipes and steel stubs, which may release $\mathrm{Fe}$ and $\mathrm{Zn}$ dusts into the atmosphere as a result of both cutting operations and the corrosion of Fe- and $\mathrm{Zn}$-based products stored outdoor. Furthermore, the sites C5 and R4 are down wind of iron-steel and coal power plants (S6), and until the 1978 two $\mathrm{Zn}$-Cu brass and bronze plants were located in an upwind position with respect to $\mathrm{C} 5$ and $\mathrm{C} 34$.

The strong difference $(t=10, P<0.000001)$ between population means of the $\mathrm{Pb}$ concentrations at the commercial sites (which is characterized by high vehicular traffic flows) merely confirms the fact that exhaust emissions from vehicular traffic was the major source of $\mathrm{Pb}$ in urban areas during the 1970s and 1980s. Furthermore, the site $\mathrm{C} 5$ is downwind to $\mathrm{S} 6$, which may represent important sources of $\mathrm{Pb}, \mathrm{Hg}$ and Cd (Pirrone et al., 1995). The downwind position of R4 to the expressway 194 (see Figure 1) may explain the significant difference between population means 


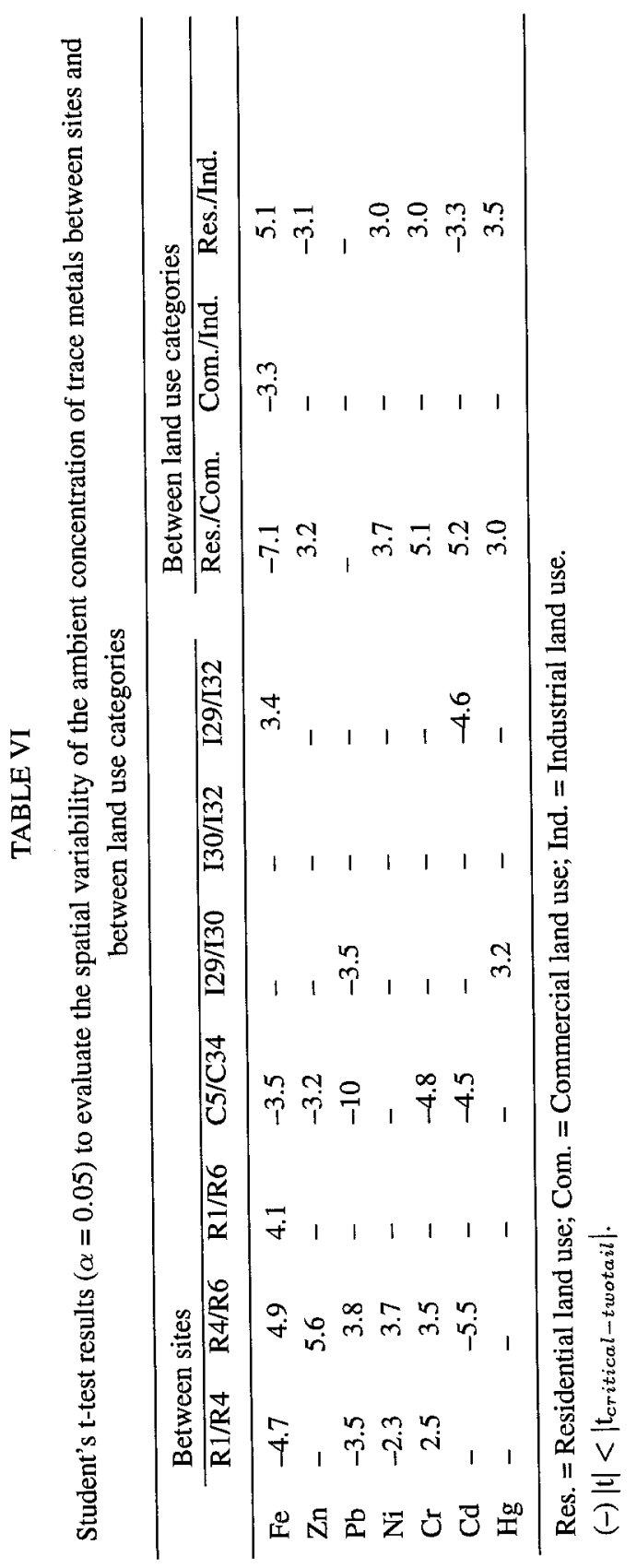


TABLE VII

Ratio between the winter and summer ambient air concentration of trace metals at sampling sites during the 1971-1992 period

\begin{tabular}{llllllll}
\hline Site & $\mathrm{Fe}$ & $\mathrm{Zn}$ & $\mathrm{Pb}$ & $\mathrm{Ni}$ & $\mathrm{Cr}$ & $\mathrm{Cd}$ & $\mathrm{Hg}$ \\
\hline $\mathrm{R} 1$ & 0.88 & 2.15 & 0.73 & 1.14 & 0.91 & 2.27 & 1.08 \\
$\mathrm{R} 4$ & 0.77 & 1.13 & 0.85 & 3.49 & 0.92 & 0.92 & 2.91 \\
$\mathrm{R} 6$ & 0.86 & 1.19 & 4.56 & 2.08 & 1.13 & 0.86 & 1.67 \\
$\mathrm{R} 12$ & 1.58 & 1.82 & 0.72 & 6.72 & 1.00 & 1.25 & 2.74 \\
$\mathrm{C} 5$ & 1.15 & 1.33 & 0.97 & 2.65 & 1.06 & 1.06 & 2.03 \\
$\mathrm{C} 34$ & 1.90 & 1.34 & 1.02 & 1.67 & 0.83 & 1.08 & 1.55 \\
$\mathrm{I} 29$ & 0.94 & 1.45 & 0.97 & 1.16 & 0.95 & 0.80 & 1.49 \\
$\mathrm{I} 30$ & 0.99 & 1.12 & 1.09 & 1.00 & 0.70 & 1.08 & 1.39 \\
$\mathrm{I} 32$ & 1.02 & 1.31 & 0.99 & 2.06 & 1.46 & 1.49 & 1.39 \\
\hline
\end{tabular}

of $\mathrm{Pb}$ at $\mathrm{R} 1$ and $\mathrm{R} 4$ with the higher variance at $\mathrm{R} 4$. Significant differences were obtained between population means of $\mathrm{Pb}$ and $\mathrm{Hg}$ concentrations at industrial sites I29 and I30, which are frequently downwind to the incinerator GDRRA (S1). The higher mean concentration of $\mathrm{Pb}$ and $\mathrm{Hg}$ observed at $\mathrm{I} 30$ can be attributed to the downwash of the plume emitted from the incinerator.

The significant difference between population means of $\mathrm{Ni}$ concentrations at $\mathrm{R} 1$ and R4 with highest variance, of $0.4 \mathrm{ng} / \mathrm{m}^{3}$, and mean concentration, $23 \mathrm{ng} / \mathrm{m}^{3}$, at $\mathrm{R} 4$, could be due to the nearby incineration of wastes containing Ni-based products (i.e. hypodermic needles, surgery knifes) at Henry Ford Hospital (S5) that is very close to R4. Cadmium concentrations show significant differences between R4 and R6, C5 and C34, and I29 and I32, suggesting important contributions from local sources. A significant amount of colored papers or small plated metal objects, disposed of by incineration at the Henry Ford Hospital may explain the higher variance and mean concentration of $\mathrm{Cd}$ at $\mathrm{R} 4$. In addition, $\mathrm{I} 32$ is also located in an industrial area downwind of automotive assembly plants (i.e. the Motor Ford Co. installations) including car-painting lines (S3).

Population means of $\mathrm{Cr}$ concentrations show significant differences between $\mathrm{C} 5$ and $\mathrm{C} 34$, and between R1, R4 and R6 with higher variance and mean concentrations at C5 and R4. Contributions from the Great Lakes Steel plant upwind to sites R4 and C5 are suggested. Possible contributions from S1 which is most often upwind of the site R4 probably should be noted. No significant differences between population means of particulate $\mathrm{Hg}$ were found between sites in residential and commercial areas. However, in industrial areas the $\mathrm{Hg}$ concentrations show significant differences between the sites $\mathrm{I} 29$ and I30 both downwind of S1. 
To evaluate the spatial variation of trace metals concentrations among land use categories, sites located in adjacent urban settings were compared pairwise using Student's t-test (population differences are given in Table VI). All the elements show significant differences between residential and commercial, and between residential and industrial population means (Table IV), with the exception of $\mathrm{Pb}$ which shows no significant variation among land use categories. The population means of ambient concentrations in commercial and industrial land use categories do not show any significant difference; Fe is the only exception suggesting that wind-blown soil particles and dust resuspension in residential areas may locally affect the spatial distribution of Fe in the urban atmosphere.

The difference in ambient air concentrations between winter and summer seasons are highlighted in Table VII. The concentrations of $\mathrm{Zn}, \mathrm{Ni}$ and $\mathrm{Hg}$ are higher during the winter season, suggesting that the effect of the seasonal activity of sources as well as the decrease of the vertical mixing height available for dispersion which frequently occurs during colder seasons, may result in an increase of the ambient concentration. Moreover, elements emitted into the atmosphere primarily as vapors such as $\mathrm{Hg}$ may be influenced by a significant increase of vapor-particle conversion during the winter season, since a decrease of the ambient temperature yields an increase of $\mathrm{Hg}$ associated with the particle phase. $\mathrm{Fe}$ and $\mathrm{Cd}$ show higher concentrations during the summer season in residential areas, confirming the assumption that the wind-blown soil particles and dust resuspension is an important source of $\mathrm{Fe}$ in residential areas; the reason for the increase of the $\mathrm{Cd}$ concentration is not known. In commercial and industrial land uses the ambient concentrations of $\mathrm{Fe}$ and $\mathrm{Cd}$ do not show significant seasonal variations. $\mathrm{Pb}$ and $\mathrm{Cr}$ concentrations are similar or slightly higher during the summer season with the exception of R6 for $\mathrm{Pb}$ with a ratio between the winter and summer ambient concentration of 4.5 . The unique future of this station may be related to the fact that the site R6 is frequently downwind of the highway 196 (see Figure 1) which has higher traffic flows during the winter season (DNR, 1989).

\subsection{LONG-TERM TREND ANALYSIS}

Figure 3 shows the long-term trend of the annual arithmetic mean concentration of trace metals for each land use category, and Table VIII gives the percentage change of the ambient concentrations in each land use category during the decades of 1971-1981 and 1982-1992. $\mathrm{Pb}, \mathrm{Ni}$ and Cd ambient concentrations were higher most of the time in commercial settings while $\mathrm{Fe}, \mathrm{Zn}$ and $\mathrm{Hg}$ were frequently higher in both commercial and industrial settings. The percentage reductions in long-term mean concentrations between the two decades were higher in industrial areas with the exception of $\mathrm{Pb}$ for which higher reductions were observed in residential areas. In the 1980s Cd concentrations showed a substantial increase in the commercial areas compared to the 1970 s. However, during the 1970 s and 1980 s the ambient 


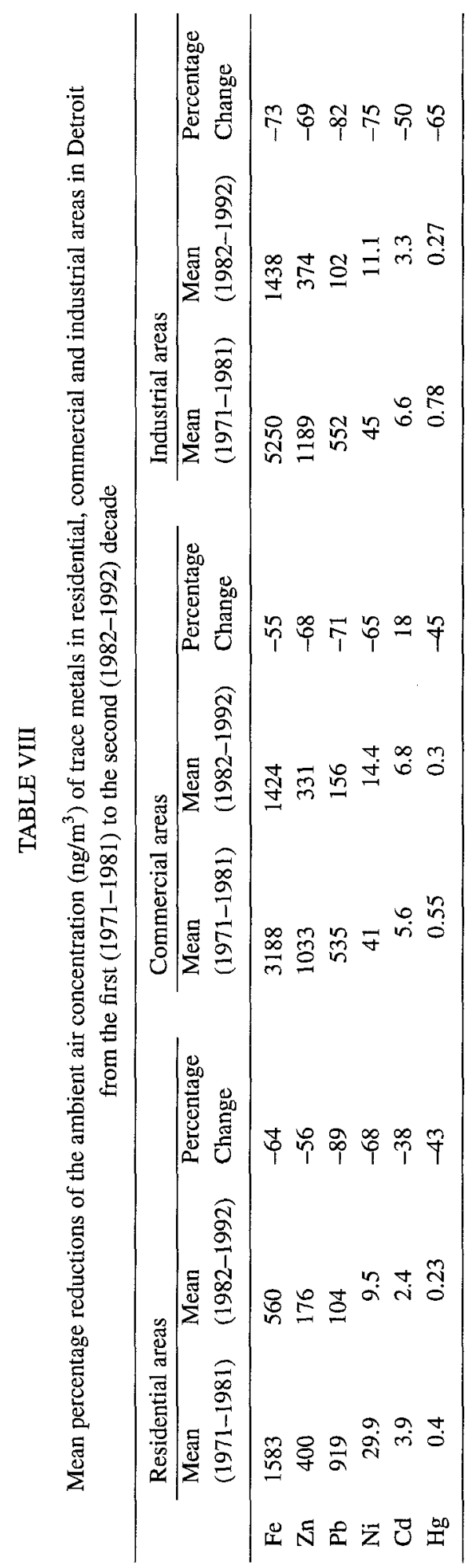



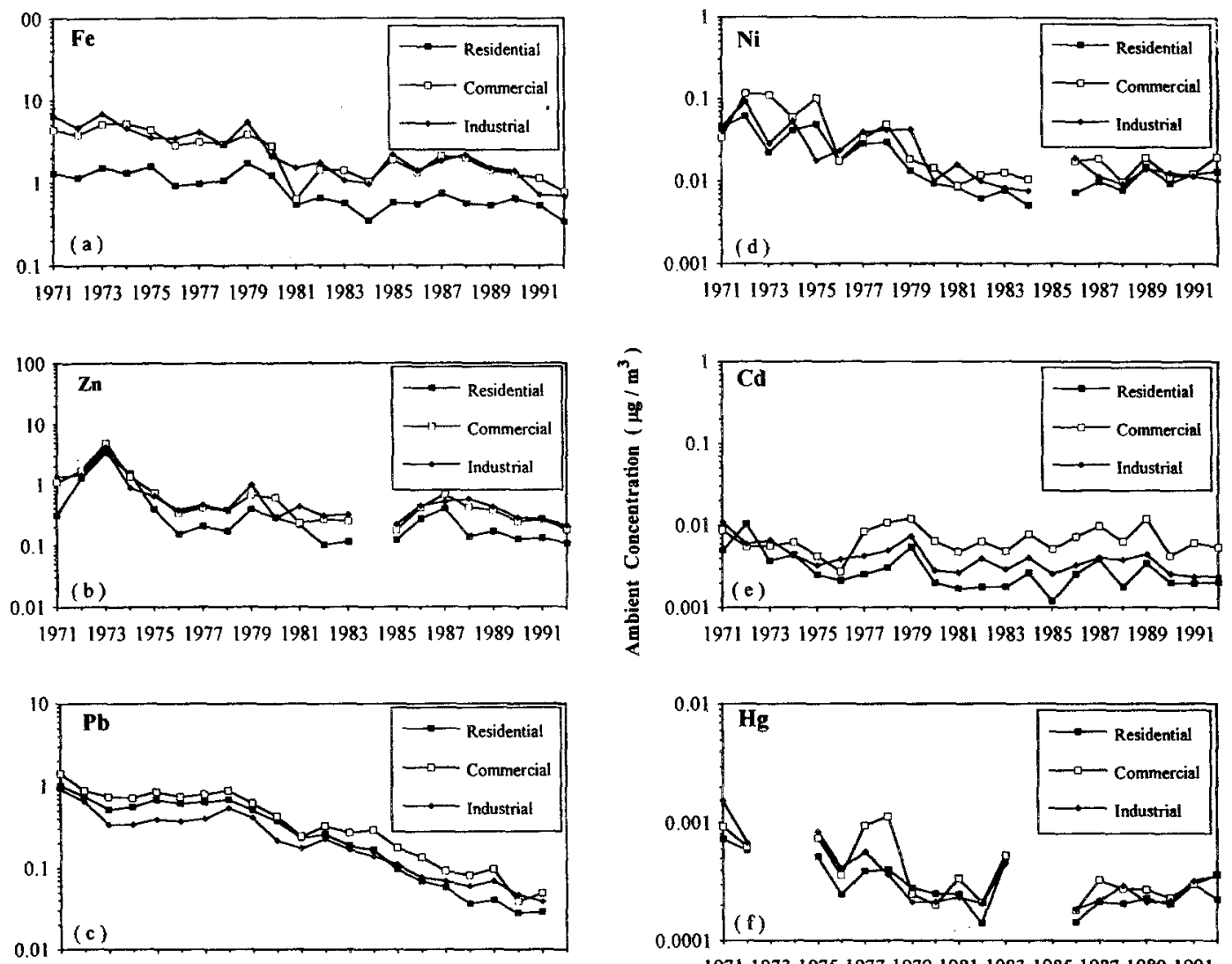

19711973197519771979198119831985198719891991

Year

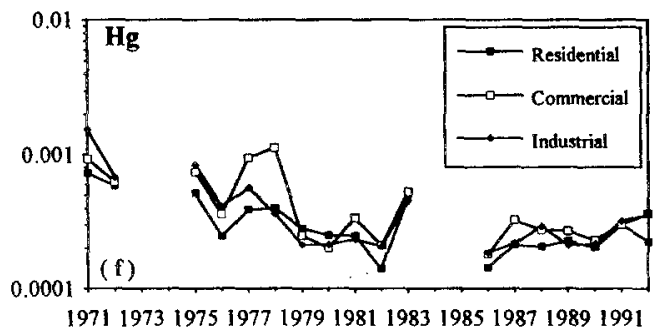

Year

Fig. 3. Long-term trends of the ambient air concentration of trace metals observed in each land use category.

concentrations of most trace metals show significant decrease (in the range of 38 to $89 \%$ ) for the entire urban scale.

Table IX gives the slope (m) and intercept (b) of long-term trends, and annual variations of ambient concentrations which occurred in Detroit during the last two decades. Ambient concentrations of all the trace metals followed a downward trend during the 1970s, achieving reductions in the range of $38 \%$ to $89 \%$ in the 10 year-period. From the 1982 to 1992 ambient concentrations of most trace metals reversed the trend with the exception of $\mathrm{Fe}$ and $\mathrm{Pb}$ which continued the downward trend over the $1980 \mathrm{~s}$ with an annual rate of $2 \%$ and $9.8 \%$, respectively. Trace metals such as $\mathrm{Zn}, \mathrm{Ni}, \mathrm{Cr}, \mathrm{Cd}$ and $\mathrm{Hg}$ were characterized by upward trends with an annual increase rate in the range of $0.6 \%$ to $10.6 \%$.

The significant change in the trend of the $\mathrm{Zn}$ concentration seems to be associated with the start up of the two new electrolytic galvanizers (S6) at the beginning of 
TABLE IX

Rate of change (slope) $\mathrm{m}=\mathrm{dC} / \mathrm{dt}\left(\mathrm{ng} / \mathrm{m}^{3}-\mathrm{yr}\right.$ ), and intercept $\mathrm{b}\left(\mathrm{ng} / \mathrm{m}^{3}\right)$ of the temporal trend of trace metals in Detroit from 1971 to $1992 . \Delta \mathrm{C}(\% / \mathrm{yr})$ is the annual variation of ambient concentrations

\begin{tabular}{cllllllll}
\hline & \multicolumn{3}{c}{ From 1971 to 1981} & & \multicolumn{3}{c}{ From 1982 to 1992} \\
\cline { 7 - 8 } & $\mathrm{m}^{a}$ & $\mathrm{~b}$ & $\Delta \mathrm{C}^{b}$ & & $\mathrm{~m}^{a}$ & $\mathrm{~b}$ & $\Delta \mathrm{C}^{c}$ \\
\hline $\mathrm{Fe}$ & -240 & 4407 & -5.4 & & -33 & 1692 & -2 \\
$\mathrm{Zn}$ & -183 & 2079 & -8.8 & & 5.8 & 163 & 3.6 \\
$\mathrm{~Pb}$ & -43 & 961 & -4.5 & & -25 & 256 & -9.8 \\
$\mathrm{Ni}$ & -5.5 & 72 & -7.6 & & 0.47 & 8.7 & 5.7 \\
$\mathrm{Cr}$ & n.a. & n.a. & n.a. & & 0.08 & 8.4 & 1 \\
$\mathrm{Cd}$ & -0.25 & 6.8 & -3.7 & & 0.028 & 4.7 & 0.6 \\
$\mathrm{Hg}$ & -0.07 & 0.95 & -7.4 & & 0.015 & 0.14 & 10.6 \\
\hline
\end{tabular}

\footnotetext{
${ }^{a}$ A negative value implies that the trend is downward.

${ }^{b} \Delta \mathrm{C}=100(\mathrm{~m} / \mathrm{b})$ is obtained selecting the 1971 as reference year.

${ }^{c} \Delta \mathrm{C}=100(\mathrm{~m} / \mathrm{b})$ is obtained selecting the 1982 as reference year.
}

the 1987. Furthermore, the large number of the incinerator facilities operating in Detroit and surrounding areas (about 1,678 units) and the start up of two major incinerators (i.e. $S 1$ with $83,160 \mathrm{~kg} / \mathrm{h}$ capacity, and $\mathrm{S} 2$ with $19,000 \mathrm{~kg} / \mathrm{h}$ capacity) during the 1980s in Detroit (Dann, 1992), may have collectively yielded an increase of the $\mathrm{Cd}, \mathrm{Ni}$ and $\mathrm{Hg}$ emissions into the local atmosphere.

However, the average annual variation in the ambient concentration of trace metals given in Table IX is certainly effected by uncertainty. In fact, the exclusion of certain years from the regression would change the slope by up to a factor of 2 .

\section{Conclusions}

A review of the airborne trace metals concentration in the urban area of Detroit from 1971 to 1992 was presented including the influence of local emission sources on the long-term trend of the ambient concentration observed in each land use category.

Most of the trace metals were found to be more aboundant in commercial and industrial areas. The observed ambient concentrations were consistent with that reported in literature for other urban areas of the world.

The trend of the ratio Cmax/Caverage was found to be similar to that observed for selected U.S. market parameters chose as long-term indicators of the emission 
sources activity, suggesting that a more detailed analysis of these parameters may be useful to understand the contrast between global versus local scale trends. The effects of type, size and location of emission sources, and prevailing meteorological conditions were found to effect the trends of the ambient concentration of trace metals in each land use category.

Long-term trends were found to be in the 1970s downward for all the trace metals with annual reduction in the range of 3.7 to $8.8 \%$. From 1982 to 1992 ambient concentrations of $\mathrm{Zn}, \mathrm{Ni}, \mathrm{Cr}, \mathrm{Cd}$ and $\mathrm{Hg}$ reversed the trend with the exception of $\mathrm{Fe}$ and $\mathrm{Pb}$ which continued the downward trend during the 1980 s with an annual rate of $2 \%$ and $9.8 \%$, respectively. However, uncertainties up to a factor of 2 were found to effect the annual rates estimate.

\section{References}

Cawse, P. A.: 1987, Trace and major elements in the atmosphere at rural locations in Great Bretain, 1972-1981, in P. J. Coughtry, M. H. Martin, and M. H. Unsworth (eds.), Pollutant Transport and Fate in Terrestrial Ecosystems. Blackwell Scientific Publications, Oxford, pp. 122.

Dann, J.: 1992, Detroit Incinerator Monitoring Program. Report No. 6, Environment Canada, Pollution Measurement Division, Ottawa, Ontario.

DNR: 1989, Air Quality Report 1989. Air Quality Division, Michigan Department of Natural Resources, Lansing, Michigan.

EPA: 1992, National Air Quality Emissions Trends. Office of Air Quality, Planning and Standards, Research Triangle Park, North Carolinea, Report 450-R-92-001.

EPA: 1993a, Emission Inventory for the Windsor/Detroit Airshed. Report prepared for the Ontario Ministry of the Environment and Energy, Interim draft - Windsor Air Quality Study, Vol. III.

EPA: 1993b, National Emission Inventory of Mercury and Mercury Compounds. EPA-453/R-93-048, interim final report.

Fidalgo, M. R., Mateos, J., and Garmendia, J.: 1988, Atmos. Environ. 22, 1495.

Gomez, M. L., and Martin, M. C. R.: 1987, Atmos. Environ. 21, 1521.

Harrison, R. M., Luhana, L., and Smith, D. J. T.: 1993, 'Urban air pollution by heavy metals: sources and trends', in Proceedings of the International Conference on Heavy Metals in the Environment, Toronto, Canada.

Kermoshchuk, J.O., and Warner, P. O.: 1981, 'A modified method for determination of ambient particulate mercury at trace levels in suspended dust', in Proceedings of the International Conference on Heavy Metals in the Environment, Toronto, Canada, pp. 81.

Keeler, G. J., Hoyer, M. E., and Lamborg, C. H.: 1994, 'Measurements of atmospheric mercury in the Great Lakes Basin', in J. Huckabee, J., and C. Watras (eds.), Mercury as a Global Pollutant: Toward Integration and Synthesis. Lewis Publishers, Boca Raton, FL, pp. 231.

Kleinman, M. T., Pasternack, B. S., Eisenbud, M., and Kneip, T. J.: 1980, Environ. Sci. Technol. 14, 60.

Lindqvist, O., Johansson, K., Antrap, M., Anderson, A., Bringwork, L., Hovsenius, G., Hakanson, L., Iverfoldt, A., Meil, M., and Timm, B.: 1991, Water, Air and Soil Pollut. 55(1-2), 30.

Lioy, P. J., Zalenka, M. P., Cheng, M. D., and Reiss, N. M.: 1989, Atmos. Environ. 23, 239.

Marshall, B. T., Cornille, P., Pacyna, J. M., and Vitols, V.: 1986, Atmos. Environ. 20, 1291.

McInnes, G.: 1979, Multi-Element Survey: Analysis of the First Two Years' Result. Report No. LR 305 (AP), Warren Spring Laboratory, Stevenage.

McInnes, G.: 1992, Multi-Element Survey: Summary and Trend Analysis 1976/1977 - 1988/1989. Report No. LR 771 (AP), Warren Spring Laboratory, Stevenage.

Meger, S. A.: 1986, Water, Air and Soil Pollut. 30, 411.

Noll, K. E., Yuen, P. F., Fang, K. Y. P.: 1990, Atmos. Environ. 24A, 903.

Nriagu, J. O.: 1989, Nature 338, 47. 
Nriagu, J. O.: 1990, Sci. Tot. Environ. 92, 13.

Pacyna, J. M., Semb, A., and Hanssen, J. E.: 1984, Tellus 36B, 163.

Pacyna, J. M.: 1987, 'Atmospheric emissions of arsenic, cadmium, lead and mercury from high temperature processes in power generation and industry', in T. C. Hutchinson, and K. M. Meema (eds.), Cadmium and Arsenic in the Environment. John Wiley \& Sons, New York, p. 69.

Pirrone, N., Keeler, G. J., and Warner, P. O.: 1995, Sci. Tot. Environ. 162, 43.

Salmon, L., Atkins, D. H. F., Fisher, E. M. R., Healy, C., and Law, D. V.: 1978, Sci. Tot. Environ. 9, 161.

Saltzman, B. E., Cholak, J., Schafer, L. J., Yeager, D. W., Meiners, B. G., and Svetlik, J.: 1985, Environ. Sci. Technol. 19, 328.

Schroeder, W. H., Dobson, M., Kane, D. M., and Johnson, N. D.: 1987, JAPCA 37, 1267.

Slemr, F., and Langer, E.: 1992, Nature 355, 434.

Smoley, C. K.: 1992, Methods for the Determination of Metals in Environmental Samples. Office of Research and Development, US-EPA, Cincinnati, Ohio.

Swain, E. B., Engstrom, D. R., Brigham, M. E., Henning, T. A., and Brezonik, P. L.: 1992, Science 257, 784 .

United Nations: 1989, Prospects of the World Urbanization 1988, Population Studies No. 112. United Nations, New York.

U.S. Bureau of Mines: 1990, Minerals Yearbook, Metals and Minerals, Vol. I. U.S. Government Printing Office, Washington.

U.S. Bureau of Mines: 1985, Minerals Yearbook, Metals and Minerals, Vol. 1. U.S. Government Printing Office, Washington.

U.S. Bureau of Mines: 1980, Minerals Yearbook, Metals and Minerals, Vol. 1. U.S. Government Printing Office, Washington.

Wilber, G. G., Smith, L., and Malanchuk, J. L.: 1992, 'Emission inventory of heavy metals and hydrophobic organics in the Great Lakes basin', in J. L. Schnoor (ed.), Fate of Pesticides and Chemical in the Environment. John Wiley \& Sons, New York, p. 27.

World Health Organization: 1992, Our Planet our Health. Report of the WHO Commission on Health and Environment, World Health Organization, Geneva. 